\title{
Analysis of the Train Station Vendors Eviction Related To University Students' Social Movement: A Case of Universitas Indonesia's Students Social Movement to The Train Station Vendors Eviction in Universitas Indonesia Station and Pondok Cina Station
}

Aprilia Nurjannatin

Aryo Akmal F.

Citra Zainuri

Patricia Amelia

Universitas Indonesia, Depok 16424, Indonesia

\section{Doi:10.5901/ajis.2013.v2n9p752}

Abstract

The research aims to describe and analyze the background, condition, and factors which cause students advocacy to the train station vendors in Jakarta, Bogor, Depok, Tangerang, Bekasi (Jabodetabek) area that will be evicted by PT Kereta Api Indonesia. This study focuses on cases that happen in Universitas Indonesia Station and Pondok Cina Station since both stations located in the researchers' university. Method that is used in this research is a qualitative approach by literature review and in-depth interview as data colleting techniques. Factors such as political situation are also considered in order to know how they motivated and contributed to the event. In the same way, the study also focuses on the cultural backgrounds within the historical context in chronological order since November 2012 untill May 2013. Historical analysis was done using approaches from other disciplines such as sociology, psychology, and political science and will also be supported by legal basis that PT Kereta Api Indonesia referred to execute the eviction, in order to obtain a broader understanding of the students's movement.

\section{Introduction}

The series of the eviction of the train station vendors in Jabodetabek area have became a social phenomenon that attracted people attentions. The eviction series started since the end of 2012 and continue until May 29th 2013 with the eviction that happened in Universitas Indonesia Station. This study focuses on cases that happened in Universitas Indonesia Station and Pondok Cina Station since both stations located in the researchers' university and had the highest level of aggressiveness and in the end triggered some conflicts.

In this study, researchers also focus to the students' social movement that happened as a form of advocacy to this case that researchers analyzed from some social theories. Which are community psychology, social psychology, social conflict theory, and social movement theory. Beside, this study explained with historical context in chronological order.

Problem formulation based on the background above are the problems from the focus of this study, which are (1) What factors that cause the eviction in Universitas Indonesia Station and Pondok Cina Station? (2) How's the chronology of the movement within series of the eviction? (3) What are the reasons and roles that students played in the eviction?

The aim of this study are : (1) To analyze factors that cause the eviction in Universitas Indonesia Station and Pondok Cina Station. (2) To analyze and explaining the chronology of the movement within series of the eviction. (3) To analyze and explain students' reasons and roles in the eviction.

Method that is used in this resaerch is a qualitative approach by literature review and in-depth interview as data collecting techniques. Literature review was done using approaches from other disciplines such as sociology, psychology, and political science. Sociology theories that used are conflict theory and social movement theory; while psychology used some theories from social psychology and community psychology. This study will also be supported by legal basis that PT Kereta Api Indonesia (PT KAI) referred to execute the eviction, in order to obtain a broader understanding of the students' movement. In depth interview as data collecting techniques done by interviewing variety stakeholders from the eviction, which are train station vendors and students of Universitas Indonesia.

One of sociological theories that used in this paper is theory of dialectical conflict proposed by Ralf Dahrendorf. Theory of dialectical conflict means people have two faces, namely conflict and consensus, because conflict 
will not happen when previously no consensus. Dahrendorf (1958) argues that each social unit is considered as imperatively coordinated association for analytical purposes, if there is an organization that creates the role of power. If the point of power on the insistence of certain parties, power relations in imperatively coordinated associations to be valid and can be seen as a normative authority relationships where certain positions are recognized and have mastered the basic rights to other parties. Power and authority is a major source of conflict and change in the patterns that have been institutionalized. This conflict is a reflection of the condition in relation to the authority. Each of these associations can be classified into two basic types of roles, the ruling and the ruled. On certain conditions, awareness of the contradictions of interests will increase, resulting polarization in imperatively coordinated associations into two opposing groups. There are three units that involved related to the train station vendors eviction which happens in several train stations in Jabodetabek area. There are PT. Kereta Api Indonesia (PT.KAI), Train Station Vendors which fused in a organization named Persatuan Pegiat Usaha se-Jakarta-Bogor-Depok-Tangerang-Bekasi (Jabodetabek) which called Perpustabek, and Universitas Indonesia's students. That each social units considered as imperatively coordinated association that have analytical purposes. (Ralf, 1958 in Soerjono, 1988. p. 77-83)

Moreover, the eviction conducted by PT KAI which is a state train and railway company, started with Presidential Decree number 83/2011 that command PT KAI to curb station area. The Presidential Decree was issued in November 24th 2011. Since then, PT KAI start to fight for their purposes by doing eviction hundreds of kiosk within the station. At first they spurce long range station outside Jakarta, then started in November 2012, they targeting Jakarta-Bogor-DepokTangerang-Bekasi (Jabodetabek) stations.

In November 26th 2012, PT KAI sent a letter to Universitas Indonesia Station which assert the kiosk owner to empty their kiosk. The letter was received by the station vendor and they spread the word to other vendors. PT KAI also anounce openly to empty the kiosk with expired contract. The vendors felt that they still have a right to use the kiosk, since their contract is still valid. The expiration date of the vendors contract is vary. The last contract, expired in May 31st 2013. So they thought that the eviction isn't right. Since the first notification letter was sent in late November 2012.

Ari, Chief of BEM Faculty of Law 2013, stated that a contract problem was the vendors weren't understand what was in it. Some of them doesn't understand about the clause inside the contract (Personal Communication, June 24, 2013). Ayu from Perpustabek, told us about this contract PT KAl gave the contract to the vendors and told them to read it and they just signed the contract when they first renting the land (Personal Communication, June 26, 2013). In few station, vendors didn't pay the rent directly to PT KAI, but to the head of station. This support the idea that actually some of them were paying to wrong person and PT KAI didn't received and extending their contract with the vendors.

One of the clause in the contract was the vendors should give back the land they use if PT KAI need it. Now, PT $\mathrm{KAl}$ wanted to expanding the platform because of the growing of passanger. PT KAl expecting 1,2 million passanger each day in 2018 (Akmal, 2013). since they have a different understanding about the contract, this problem continue to be a bigger problem, because everyone think they were right, especially it makes one of the vendors in Universitas Indonesia station named Ayu, realized that she has to do something to fight for the vendor's right.

Ayu contacted Universitas Indonesia alumni, Suma Miharja. He was explained about the condition and stated he will support and advocating the vendors if they want to fight for their right. Bu Ayu also searching for students support. They know that there is official students organization called Badan Eksekutif Mahasiswa (BEM) or Students Organization Body, so she searched for BEM member contact number. She asking most of her customer whether he or she was member of BEM. Finally she managed to get the number of Chief of BEM Universitas Indonesia 2012, Faldo Maldini. She contacted Faldo that night and explained the condition. Faldo promised that he will be there tomorow with 30 students. The quick respond from the Chief of BEM UI 2012 and all of the students that directly came to help the vendors from eviction in Universitas Indonesia Station and Pondok Cina Station can be associated to the theory of sense of community - the McMillan-Chavis model that says one of the elements of sense of community is having invested part of themselves in the community, and of belonging to it (D. W. McMillan \& Chavis, 1986 in James, Maurice \& Abraham, 2001. p. 194). The first attribute of the boundaries and for this case a locality involves geographic boundaries, for a relational community (James, Maurice \& Abraham, 2001. p. 194). This explains why students feel that they have to concern and give a big attention to this case, because this case involve part of their own community that is the train station vendors, because they live together in same area that is Universitas Indonesia, both Universitas Indonesia Station and Pondok Cina Station.

Beside of Universitas Indonesia Station that clearly is part in Universitas Indonesia area, Pondok Cina Station have long been a students' book store. Vendors sell cheap and old books for the need of students. Most of vendors already know which book the students need based on their faculty and class. Thus, most students feel gratefull for what vendor's activity. The first eviction with students direct involvement was Lenteng Agung Station in December 30th 2012. Fully 
equiped join force from Police and Army securing the eviction. They also supporting PT KAI internal security force and eviction task force.

Students and join force involve in direct contact when students and vendors crowd tried to cancel the eviction. Some of the students got hit by the police which is equipped with heavy gear and injured. Ali, Chief of BEM UI 2013, fall from the platform to the rail way and some of the vendors injured by the act of the police. Violence, is a behavior designed to inflict injury to people or damage to property (Hugh, 1969 in Ron \& Robert, 1979. p. 5). According to Graham's definition of violence, this incident was explained the meaning of violence itself. These also defined what Ron E. Roberts (1979) said in his book, "Social Movements: Between the Balcony and the Barricade" about reactionary violence. Reactionary violence represents attacks by loosely organized groups againts elites who in some way took away rights they once enjoyed; hence the label "reactionary" (Ron, 1979).

After the Lenteng Agung eviction, students and vendors tried to consolidate their movement. Story about how harsh police treated the students and vendors was massively spread. This story ringing a bell and the other students started to noticing this evection problem. Hanif, Chief of BEM FISIP 2013 stated that this story built solidarity within the students (Personal Communication, June 18 2013). After that other students started to be involved in the movement. Ari, Chief of BEM Faculty of Law 2013 told that, their conscience and intelectuality support what they have done to help the vendors (Personal Communication, June 24, 2013). This represents Hans Toch's state about social movement. Hans Toch (1965) stated that a social movement represents an effort by a large number of people to solve collectively a problem that they feel they have in common. Movements are a special kind of social collectivity that is not organized, but may have members who belong to organized groups; therefore, a movement is a social collective that has some element of planning or goal orientation within it (Hans, 1965 in Ron \& Robert, 1979. p. 14).

The main objective of the students was helping vendors with their movement. Faldo told that vendors were very diffrent from the students, therefore studenst involved in the early movement tried to help them and directing what they should and could do (Personal Communication, April 2, 2013). Law students tried to analyze vendors and PT KAI contract, psychology students help vendors by establishing Psychology First Aid which help psychologycal problem that occur after the eviction. Faldo stated that students have no interest in this eviction, they just wanted to help (Personal Communication, April 2, 2013). Thus students demand in the movement was also vendors demand which is comprehensif dialogue with PT KAI. Since, most of eviction occured without any dialogue.

The students also seeking external help. Legal Aid Jakarta was appointed to be vendors attorney and they also report to National Human Right Commision in Indonesia which called Komnas HAM, asked them to ask PT KAI to delayed and abort the eviction untill dialogue occur between PT KAI and vendors. Vendors believe that PT KAI already violated their right working because conducting eviction without dialogue. This social movements are reactions on the part of individuals and groups to unsatisfactory conditions in social life (Jerome, 1930. in Ron \& Robert, 1979. p. 12). There is a maladjustment which causes mental and social friction, and the movement develops as an effort to bring about harmony. These also one of many societal problems as economic at base.

As Dahrendorf (1958) said that conflict is driven or inhibited by various structural conditions or variables and it proved in the eviction that happened in Pondok Cina Station, because this eviction attracted students attention. It happened in holiday season, makin only handful of students come to campus area. The students and vendors that involve in the movement, went to Presidential Palace that morning to conduct a demonstration. But, that morning, in Pondok Cina Station came a group of PT KAl eviction task force with few hoodlums. Ayu told that, since most of vendors went to Presidential Palace, there were only women and old man in that area of kiosk (Personal Communication, June 26, 2013). Few students were also there, when the task force and hoodlums came to the station. Faldo Maldini was called to be informed about this matter and he went straight to Pondok Cina Station. The eviction already started when Faldo arrived with hoodlums break few kiosk. Students tried to defending the kiosk got hit with a crowbar by this hoodlums. This incident also explained Graham's definition of violence, as written above. The main problem here, why they need someone to do it with violence to hurt people and destroy the kiosks, here we can see that actually they just do what they've been told to do, they do not feel wrong to do such things, and this is brings us to the understanding of obedience in social psychology that one person simply orders one or more others to perform some actions of what they want (Robert \& Nyla, 2012. p. 255). Thus they don't feel wrong because that role that was given to them by PT. KAl.

Crowd of students and vendors which on their way to Presidential Palace informed about this event and turned back to campus. Students with motorcycle went straight to the campus while other use train from Djuanda Station near Presidential Palace. Faldo said that almost six cars of train filled with angry vendors arrived in Pondok Cina Station. Vendors and students were questioning this eviction because no vendors were noticed about PT KAI plan to evict Pondok Cina Station that day. . These explained Smelser's fifth determinants of collective behavior: Mobilization of the 
participant for action. This is a function of both communication and persuasion of the masses that they should take drastic collective action (Ron \& Robert, 1979. p. 38)

When students from Presidential Palace demonstration arrived in Pondok Cina Station and seeing their friend got hit and injured, most of them got angry. They chased the hoodlums and seek for revenge. But their leader told them not to interact with the hoodlums. Therefore, conditions above can be said become the variables that driven the conflict getting worse.because of the situation that getting worse, we can see that aggression behavior appeared even not only from hoodlums, but also from the students which at first they refused to do anarchy in their movement. Philip Zimbardo (2007) explained this situation which is a key point about human behavior is the situation in which people find themselves - not their actually personal traits. The result of the experiments lead him to suggests that it is this tendency to yield to situational pressures - including conformity pressures - that is responsible for much evil behavior (Zimbardo, 2007 in Robert \& Nyla, 2012. p. 264). Baron and Brascombe (2012) mention in their book, Classic studies in social psychology on deindividuation explained that people self awareness can be reduced and encourages to do wild and impulsive behavior in some conditions such as When people feel anonymous, they do perform actions they would not perform under other conditions. Also when people are part of a large crowd, they are more likely to obey the norms of the group, and do what others are doing (Postmes \& Spears, 1998 in Robert \& Nyla, 2012. p. 311).

Angry vendors wanted to meet with in charge person in that eviction but failed. Because of that they shut down the rail road and causing Commuter Line Jakarta, which is very busy, to be delayed. At first, vendors wanted to destroy station's office. They already prepared gasoline and fire to burn down the office. Students tried to calm the vendors down untill they came up with this blocking rail idea to express their anger. Karl Marx, although not writing a spesific sociology of movements, deals with class struggle in such a systematic way as to constitute a theory of social change that is all encompassing. Marx saw the final movement or class action as one generating out of the final clash between the forces of one clash and another. In this case, Marx's sight about social movement was well-explained.When the students finally decided to involve in blocking the rail, actually they do understand that behavior can trigger another problems such as legal problem, new conflict between new people, loss for PT. KAI, and many more. Basically they start the actions when they see the aggression behavior from the vendors who destroy fences and thing around the rail and put it on top of the rail. The behavior occurs when actually the vendors feel frustration because they feel everything prevents them from reaching goals they are seeking - thus, that feeling leads to the arousal of a drive whose primary goal is that of harming some person or object (berkowitz, 1989. In Robert \& Nyla, 2012. P. 325) also in that such big crowd there are a lot of people that start a provocation, in physical or verbal, which is also one of the basic sources of aggression (Robert \& Nyla, 2012. p. 328).

Since the blocking delayed the Commuter Line Jakarta, many passangers were angry. They walk from Universtias Indonesia Station to Pondok Cina Station and confront vendors and students there. Because of the passanger were protesting what vendors did, and they done that in quite long time, so they ended the blocking. Conflict resolution may lead to a situation which led to another conflict between the forces opposing like Dahrendorf said in his theory.

\section{Universitas Indonesia Station Eviction}

Universitas Indonesia Station were evicted on May 29th 2013. Join force from Police and Armed force securing the site. Universitas Indonesia main gate were closed because of this eviction. There are almost 1000 officer from Police, Armed Force and PT KAI Security force. Eviction task force were helped by PT KAI Security force and train technican.

Students and vendor crowd were about 150 people. Many of Universitas Indonesia Station vendors already emptied their kiosks, only few fighting PT KAI plan. Students was told to be at the station at 8 in the morning, but the eviction started at 7 . So without preparation and enough people, students and vendors cannot defend the kiosk.

Clash between the crowd and police is not very intense because students and vendor were out numbered by the police. There are short time stone throwing but ended in no time. Many of the vendors, mostly woman, were crying and screaming to the eviction task force asking them to stop whay they did.What students can do is helping the vendors and tried to calm them. Few studend making a speech in front of the station while eviction task force doing their job to demolish the kiosk. Media were also there to report Universitas Indonesia Station eviction.

PT KAl as station operator have done a contract with vendors since 1986 when a vendors still do business in platfrom. This way, vendors was disrupting train users interest. Then PT KAI built kiosk on the edge of the platform to accomodate vendors. Vendors bought the building and rent the land. That time, old vendors, the one whose already vend in platform was charged Rp 15 million and rent the land for Rp 1 milion per year. This way, vendors owned the building. The new vendor who wanted to buy a kiosk charge with Rp 22 million and same amount for land rent. 


\section{Another Form of Movement}

PFA were established by Psychology Faculty BEM to help and manage vendor after eviction. Ananda Findez, Chief of BEM Faculty of Psychology said this form of movement begun when they found a kid that told them he wanted to become a soldier and have a vengence to these people who destroyed their kiosk, and psychologically this kind of idea inapropriate so need to be handled (Personal Communication, June 24, 2013). Psychology students in the field also found that most students and people around the incident doesn't understad how to interact with vendors after the eviction that happened to them. This is a different form of movement from Universitas Indonesia students. Some of them do the advocation and go to the street doing demostration. But some also do this kind of thing, based on their experties.

Beside rally and PFA, students also register train stasion vendors in order to be keep in touch and efective coordination. This data will also be use to help the vendors in the futere. Students also tried to spread the story about this eviction via social media such as twitter, facebook and tumblr. They write about the eviction on tumblr, facebook twitter and other blog, posting a video on youtube or campaigning with hastag in twitter. They tried to attract people attention to this matter and what they think is wrong about this eviction.

Going to Komnas HAM and other goverment body also part of the movement via institutionalize procedure and hoping that goverment can help them and the vendors to achived their goal and defending what they think the right of the vendors.

\section{Conclusion}

Students thought that there are something wrong about this eviction by PT KAI so they move to help and advocating the vendors. Their conscience and intelectuality also support what they have done all along. Solidarity within the students also move other to help the vendors. Solidarity came when they knew what happened to their friend in the field. Their goal was to help vendors with their own movement. They told the vendors what they could and should do.

Problem occur when the execution were contract validity, usage of hoodlums in the eviction, procedural problem, and moment and time of eviction. Violance which students and vendor counter when the eviction also the problem causing injury to them. Althogh most of the station already evicted, but some students and vendors still tried to fight what PT KAl have done. They arrange Class Action to PT KAl and hope they still manage to received their right.

It concludes that we can explain this phenomenon as a conflict situation which happened between PT KAI and train stations vendors and triggered Universitas Indonesia students's to help them by doing advocating vendors. But this advocacy ended up seen as an mislead social movement even there are still other forms social movement that Universitas Indonesia's students did such as PFA.

\section{References}

Baron, R. A., \& Branscombe, N. R. (2012). Social Psychology (13 th ed.). New Jersey: Pearson Education. Inc.

Dalton, J. H., Elias, M. J., \& Wandersman, A. (2001). Community Psychology: Linking Individuals and Communities. USA: Wadsworth.

Hidayat, A. (2013, May 23). PT KAl Targetkan 1,2 Juta Penumpang di 2018. Indonesia Finance Today. Retrieved from http://www.indonesiafinancetoday.com/read/45574/PT-KAl-Targetkan-12-Juta-Penumpang-di-2018

Jackson, M., \& James, W. (1982). Social Movements:Development, Participation, and Dynamics. Wadsworth Publishing Company. Belmont: California.

Kamaruddin, S. A. (2012). The Peasants' Revolt of Unra 1943 (A Case of Social Movements in South Sulawesi under Japanese Occupation. Makara, Sosial Humaniora, Vol. 16, No. 1, 19-35

Roberts, R. E., \& Kloss, R. M. (1979). Social Movements: Between the Balcony and the Barricade. London: The C.V. Mosby Company

Soekanto S., \& Lestarini, R. (1988). Fungsionalisme dan Teori Konflik dalam Perkembangan Sosiologi. Jakarta: Sinar Grafika. 